https://doi.org/10.52449/1857-4114.2021.37-1.05

CZU: 159.9:796.015

\title{
THE CONTRIBUTION OF PSYCHOLOGICAL AND BIOLOGICAL ENERGY TO INCREASING THE QUALITY OF SPORTS TRAINING FACTOR INDICES
}

\author{
Dumitru Răzvan Constantin ${ }^{1}$, ORCID: 0000-0003-4263-1081 \\ Grimalschi Teodor ${ }^{2}$ \\ 1 "V. Alecsandri" University, Bacau, Romania \\ ${ }^{2}$ State University of Physical Education and Sport, Chisinau, Republic of Moldova
}

\begin{abstract}
The personality of the athlete is capitalized by the totality of his psychic, physical and functional qualities and functions as a biopsychosocial model of the set of internal and external factors, which has a meaning of adaptation to sports training efforts, in the integrity of its dynamicenergetic aspects, at the physical-material level, emotional, mental, energetic, transcendental and spiritual.

Sports training is based to a large extent on the quality of the indices of physical training factors, technical, functional, psychological, etc. Based on the control of the body's reaction to effort, new models of sports training are planned. The theory and practice of sports training also needs to supplement the knowledge of notions, ideas, information of the contribution of psychic energy and biological energy to streamlining the quality of bio-psycho-electromagnetic parameters of the athlete to create a model of athlete with higher energy potential. The model of a performance athlete consists of specific cellular models with integrative electrical characteristics. In bioenergy, the term "integration" is used to describe the magnetic movement in the body from the head (psychic energy), the trunk to the lower limbs (biological energy), and vice versa without blocking, forming a bio-psycho-electromagnetic circuit.

Psychic energy is a state of consciousness, of energy challenge, including alpha waves in the posterior brain. Stimulates energy centers for overcoming the mental state, consciousness, cultivating emotional intelligence, energy ability, etc. Biological energy stimulates the meridians of the internal organs, the energetic harmony of the neuromuscular system of the arms and lower limbs.
\end{abstract}

Based on special research, the structure of the interaction of human energy was developed, forming an algorithm of harmony between the groups of psychic energy and biological energy.

There were 5 (five) levels of electromagnetic energy potential: high, medium high, medium, minimum and very low with variations in the value of the electric field component from - 0.116 to 2.998 quanta depending on time.

Keywords: athletes, sports training, quality, psychic energy, biological energy, magnetic field, integration, bio-psycho-electromagnetic energy, energy skills.

Actuality. In recent years, the attitude regarding the development of the field of sciences of psychopedagogy, medical biology, biomechanics, physical culture and sports is being reconsidered, and the theories and methods of other sciences find an application at the beginning of their path in these sectors. The multidisciplinary approach, such as biopsychosocial culture, biopsychosociopedagogy, bio-psycho-electromagnetism, psychic energy, biological energy, proposes solving problems, systems, complex situations 
dependent on several scientific disciplines and organizational principles, which stimulates the ability to integrate information and at the level of updated problems $[1,4,7]$.

According to C. Guja, it is outlined that the bodily existence corresponds to an energetic-informational existence, which evolves in parallel with the physical body and which could transcend the continuity of information and individuality [4, p. 236]. The living organism is in an electromagnetic field as a conductor and at the same time a bioelectric generator [10]. The structure of the athlete's personality is defined by its own biomagnetic field that undergoes permanent varieties from one training to another, from one mesocycle to another by interacting with the magnetic components of general radiant electromagnetic fields from various sources of the Universe [8].

In order to achieve the main goal of the contribution of bio-psycho-electromagnetic energy to the efficiency of sports training meeting the needs of coaches and, consequently, obtaining a benefit of mental, physical and energetic state, it is necessary to study and capitalize on the components of mental and biological energy in relation to the requirements of the instructive-educational process. Also, the structure and strategy for promoting the energy product achieved in the field of sports training must be developed by capitalizing on energy-based cognitivebehavioral therapy [3, p. 61-63]. Based on our considerations, which we will present, is the hypothesis that the message of the teachercoach during sports training brings an integration of knowledge, there is the equivalence of psychic energy and vice versa, psychic energy is transformed into information [4, p. 61]. Psychic energy is connected inside the organs, biological energy, forming an electrical network through which energy flows [5, p. 418-420].

The internal energy focus is the point of concentration of actions and feelings of being up to the quality situation at a given time during a valuable sports activity.

The aim of the research lies in the analysis of the particularities of the contribution of psychic energy and biological energy in increasing the quality of sports performance factors. Achieving the intended goal involves achieving the following objectives:

1. Examination of the theoretical and practical center regarding the extension of the conception of energetic potential and energetic aptitude.

2. Elucidation of the impact of the activity environment on the operation of the magnetic component source.

3. Identification and elaboration of the factors influencing the psychic energy and the biological energy on the human organism.

Scientific research methodology. The methodological and theoretical-scientific support of the paper is the modern scientific conceptions regarding the legitimacy of the development of the interaction skills of the electromagnetic fields. The following methods were used for the material analysis of the topic:

1. The logical method with its operations analysis, synthesis, deduction, generalization, for the coherent investigation of all aspects of psychic energy and biological energy.

2. The comparative method in the aspect of the integrity and interaction of electromagnetic fields.

3. Method of morphological analysis, structure and content of human energy interaction.

The theoretical-scientific foundation focuses on the studies of specialists developed in the field of electromagnetic field energy.

The novelty and scientific originality of the paper consists in: establishing a conceptual framework specific to bio-psychoelectromagnetic energy based on its mission in sports activity, taking into account the requirements of the learning process of sports classification program; retrieving information through training and determining the typology 
between various levels / types of the electromagnetic field.

The results obtained.

Through scientific research it has been observed that the value of the magnetic field with low intensity -0.116 and -0.120 quanta produce sensations of physical, functional and psychological deficiency, unfavorable educational ambitions through the psychosocial climate in team training. Unidirectional communications occur during the training process in the development of intellectual, ethical, aesthetic, physical strength, endurance and mobility. Cliché words used in learning the elements of difficulty, expressed by the teacher-coach produce serious mental disorders. The words "get out of here", "never to see you again", "you're lazy" and so on repeated to the child many times in the mental image, in the subconscious is translated and transformed into information of conditioned language, in such risk situations the athlete falls into depression, may reach psychosomatic disorders, correspondingly decrease the effects of electromagnetic biofield and quality of classification elements, especially at the age of 7-9 years. Low values of the magnetic component at this age were also observed in the research of V. Ionescu [6]. For this reason, the coach teacher is obliged to know the transmission of electromagnetic information of the body that suffers permanent varieties, by interacting with the magnetic components of electromagnetic fields depending on the year of birth.

Figure 1 shows the contribution of energy in the interaction of psychic energy and biological energy. When energy waves are not balanced by bioelectromagnetic communi- cation, undesirable changes in attitude and behavior occur during physical activity. The effects can be manifested in the training process by balancing the spirit, the qualitative functioning of the organism but also of the neuromuscular tissues [1, p. 49].

Electromagnetic communication is important in scheduling sports and competitive training, providing scientific support and a training model for athletes, eliminating inhibitions and complexity of disciples on all levels: energetic, physical, emotional, spiritual and mental. It must be recognized that energy information, as a functional system, according to P.C. Anohin and I.P. Pavlov, quoted by L.G. Pucico [9, p. 18] is connected to every organ and tissue, is transmitted from the brain as a device for self-regulation of capacity their functioning [8, 10, 11]. Energy transfer is based on mechanical means, sports training, by continuous action, such as switching from hanging to support and vice versa when performing a combination on gymnastic devices that generate electromagnetic field. As a result of energy consumption, the internal economy of the muscle cell is disorganized. However, compensatory mechanisms intervene that not only restore the muscular system, but also increase its mass and functional capacity through the energy increase they bring, develop energy aptitude [2, p. 178]. The energetic aptitude of the athlete is balanced with the emotional intelligence, it has two components:

1 It is based on the awareness that the body's energy changes from one gymnastic apparatus to another.

2. The cultivation of energy fitness is based on the ability to influence those energies so as to be beneficial and efficient for the body in training and sports competitions in quality. 


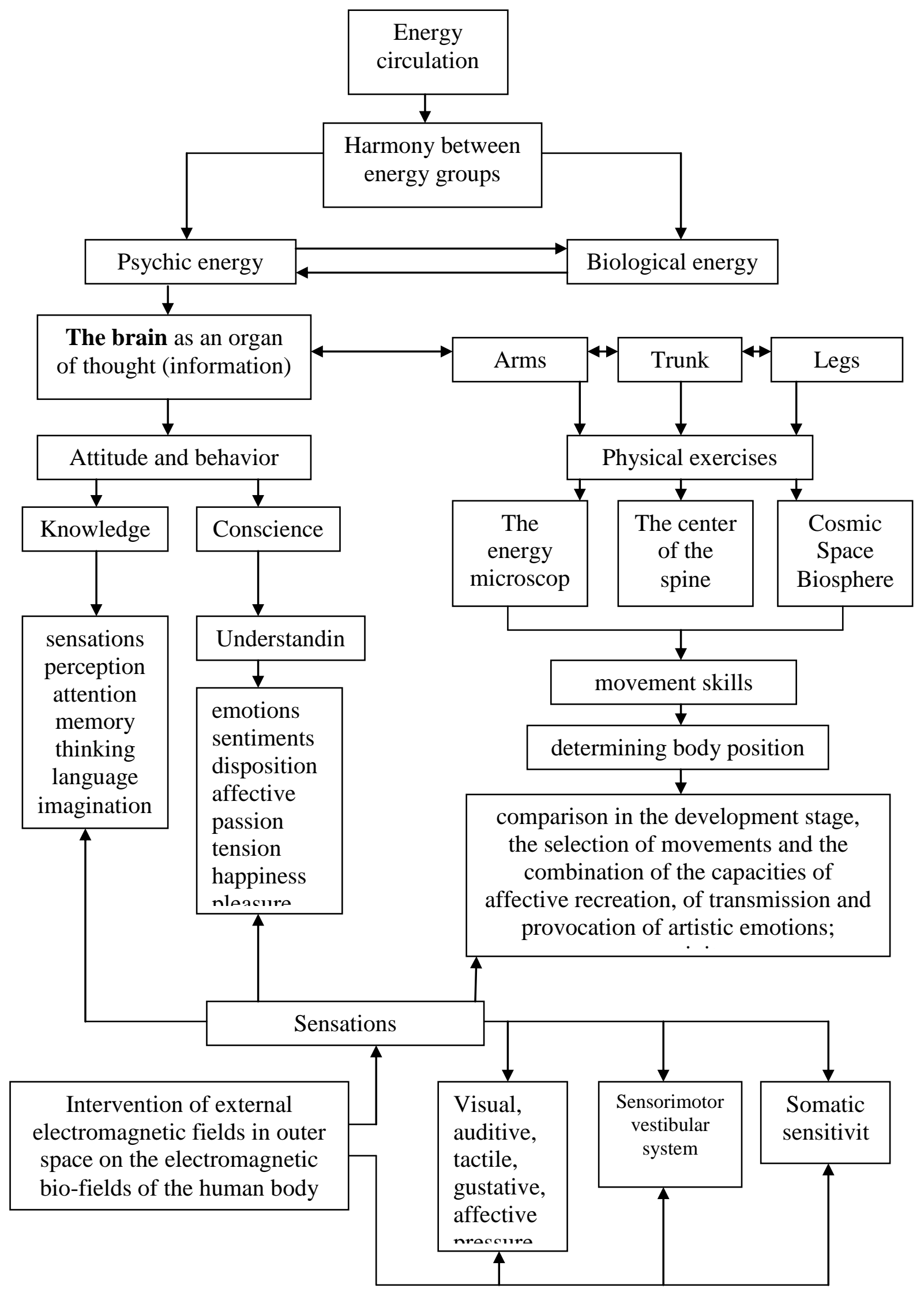

Fig. 1. The interaction of human energy 


\section{Conclusions:}

1. The study of the literature showed that in the system of sports and competitive training in gymnastics are not fully published papers with an adequate methodological content based on the contribution of mental energy and biological energy in streamlining the physical and intellectual performance of the athlete. The energetic aptitude of the athlete and the value of the magnetic field in increasing the level of sports performance are not studied.

2. The energetic aptitude of the language of learning the contents of the sports classification program represents an activity on which the whole psychic organization of the sports training is structured and developed, it is a code for transmitting the bio-psychoelectromagnetic informational processes.

3 . The problem researched by us must tend towards a certain degree of perfection and the increase of the quality of the indices of the sports training factors, the development of the intuitive capacities that has many beneficial effects, in qualitative aspect: - a better health; a good disposition of physical and intellectual work; - stimulating creativity and technicalartistic improvisation; - psychic and biological energization; - increased control over magnetic movement through the body; - a more rational regulation of efficiency; - recognition and awareness of the superior forces of the magnetic component of the electromagnetic field that monitors our life; - less stress.

\section{References:}

1. Eden D., Feinştein D. (2009). Energiile corpului. Metode de echilibrare a energiilor pentru sănătate şi vitalitate. În: Medicina energetică pentru femei. Iaşi: Polirom, p. 49.

2. Feinştein D., Eden D., Craig G. Aptitudinea energetică. În: Psihologia energetică. Iaşi: Polirom, 2011, p. 178-179.

3. Grimalschi T. (2019). Valorificarea terapiei cognitive-comportamentale bazate pe energie. În: „Sport. Olimpism. Sănătate.”: Congres Ştiinţific Internaţional consacrat Zilei Internaţionale a Sportului Studenţesc. Culegere de rezumate, ediţia a IV-a. Chişinău: USEFS, p. 61-63.

4. Guja C. (2000). Aura corpului uman. Introducere în antropologia individului. Iaşi: Polirom, p. 61, 236.

5. Lin H. B. (2006). Secretele medicinei chineze. Iaşi: Polirom, p. 304-306.

6. Ionescu V. (1996). Zodiacul chinezesc. O abordare ştiinţifică. Bucureşti: Coresi, p. 304306.

7. Ţugulea A. (1994). Câmpul electromagnetic. Bucureşti: Tehnica, p. 205.

8. Капица Г. (2000). Биоэнергетический обмен между людьми. В: Анатомия биоэнергетического обмена. Школа биоэнергетики. Санкт Петербург: 3АО «Весь». 151 с.

9. Пучко Л.Г. (2004). Многомерная медицина. Система самодиагностики и самоисиеления человека. Москва: АНС, с. 18.

10. Хван Ю. (2002). Человек - энергетическое существо, а не только физический организм. Санкт Петербург: Прайт Еврознак, с. 53-56.

11. Becker R.O. (1978). Evidence for a Primitive DC Electrical Analog System Controlling Brain Function. În: Subtle Energies, vol. 2, no 1, p. 71-88. 